\title{
POLISHED HOUSEHOLD THINWARES FROM SAN PEDRO DE ATACAMA, CHILE: REFLECTIONS ON SHAPE AND COLOR
}

\author{
LA CERÁMICA PULIDA DELGADA DESDE UN CONTEXTO \\ DOMÉSTICO DE SAN PEDRO DE ATACAMA, CHILE: \\ REFLEXIONES A PARTIR DE SU FORMA Y COLOR
}

\author{
Emily Stovel $^{1,2}$ and Ester Echenique ${ }^{3}$
}

\begin{abstract}
This article presents a characterization of polished thinwares found at the site of Coyo Aldea contextualized by recent scholarly advances in the transition between the Formative and Middle Periods (ca. AD 100-700) in San Pedro de Atacama, northern Chile, and the Andes. In particular, we explore polished household thinwares by juxtaposing them against similar polished vessels common in local graves. Clarifying variation within residential types and between these and burial types allows us to better understand household ceramic consumption at this time and the potential ritual role burial ceramics played in defining new social complexity. This work prompts us to look again at how local material culture functioned in the negotiation of power in the mortuary context while reinforcing the persistent need for more systematic excavation of household contexts.
\end{abstract}

Key words: Late Formative Period, Middle Period, ceramic analysis, household archaeology, San Pedro de Atacama.

En este artículo presentamos una caracterización de la cerámica pulida delgada procedente del sitio de Coyo Aldea en relación con la literatura reciente sobre la transición del período Formativo al período Medio (ca. 100-700 d.C.) en San Pedro de Atacama, norte de Chile y los Andes circumpuneños. Con el fin de contribuir a un entendimiento más comprensivo de la cerámica prehispánica de esta región, examinamos la cerámica pulida delgada utilizada en contextos domésticos en relación con la cerámica pulida de los entierros locales. Aclarando la variabilidad entre los tipos cerámicos habitacionales y su comparación con los tipos cerámicos de entierros, nos permite acercarnos a una mayor comprensión del consumo de la cerámica en estos períodos y del potencial rol ritual de la cerámica mortuoria en la definición de una nueva complejidad social. Este trabajo llama a redirigir la mirada a la cultura material local y su función en las negociaciones de poder en los contextos mortuorios; al mismo tiempo confirma la necesidad de ejecutar excavaciones más exhaustivas de contextos habitacionales.

Palabras claves: período Formativo Tardío, período Medio, análisis cerámico, arqueología doméstica, San Pedro de Atacama.

The social processes of the Formative or Early Intermediate Period have long been a pivotal area of focus for Andean scholars. It is the moment when sedentism, agricultural practices, interaction spheres and social complexity consolidate in many regions. Scholars have emphasized the role of ritual behavior, interaction, and power in this transitional moment, such that incipient social complexity uses local and nonlocal social capital to rethink relationships and status, the definition of family, and political office (Hastorf 2008; Janusek 2004, 2006; Roddick and Hastorf 2010; Vaughn 2006). These changes provide the foundation for later states and supra-regional polities, and define the nature of nonlocal interaction, craft production, and the acquisition of exotic raw materials and finished objects. As status is consolidated through special access to elite goods, this access must be publically visible, and it would appear that mortuary ritual is an important area for the materialization of such power and access (Baker 2012; Ekengren 2013; Harper 2010, 2012; Potter and Perry 2011).

Recent research in San Pedro de Atacama in northern Chile (Figure 1), has offered vital insights into the social developments of the Formative Period $(1,300$ ? BC-AD 400; Table 1). Settlements became more permanent, ceramic production became more systematized, and hunting, gathering, and pastoralism were more regularly accompanied by agricultural activities (Adán and Urbina 2007; Agüero 2005;

\footnotetext{
SWCA Environmental Consultants, 5647 Jefferson St., Albuquerque, NM, USA 87109. estovel@ swca.com Instituto de Investigaciones Arqueológicas y Museo (IIAM), Universidad Católica del Norte, San Pedro de Atacama, Chile. School of Anthropology, The University of Arizona, Tucson, USA. eecheniq@email.arizona.edu
} 


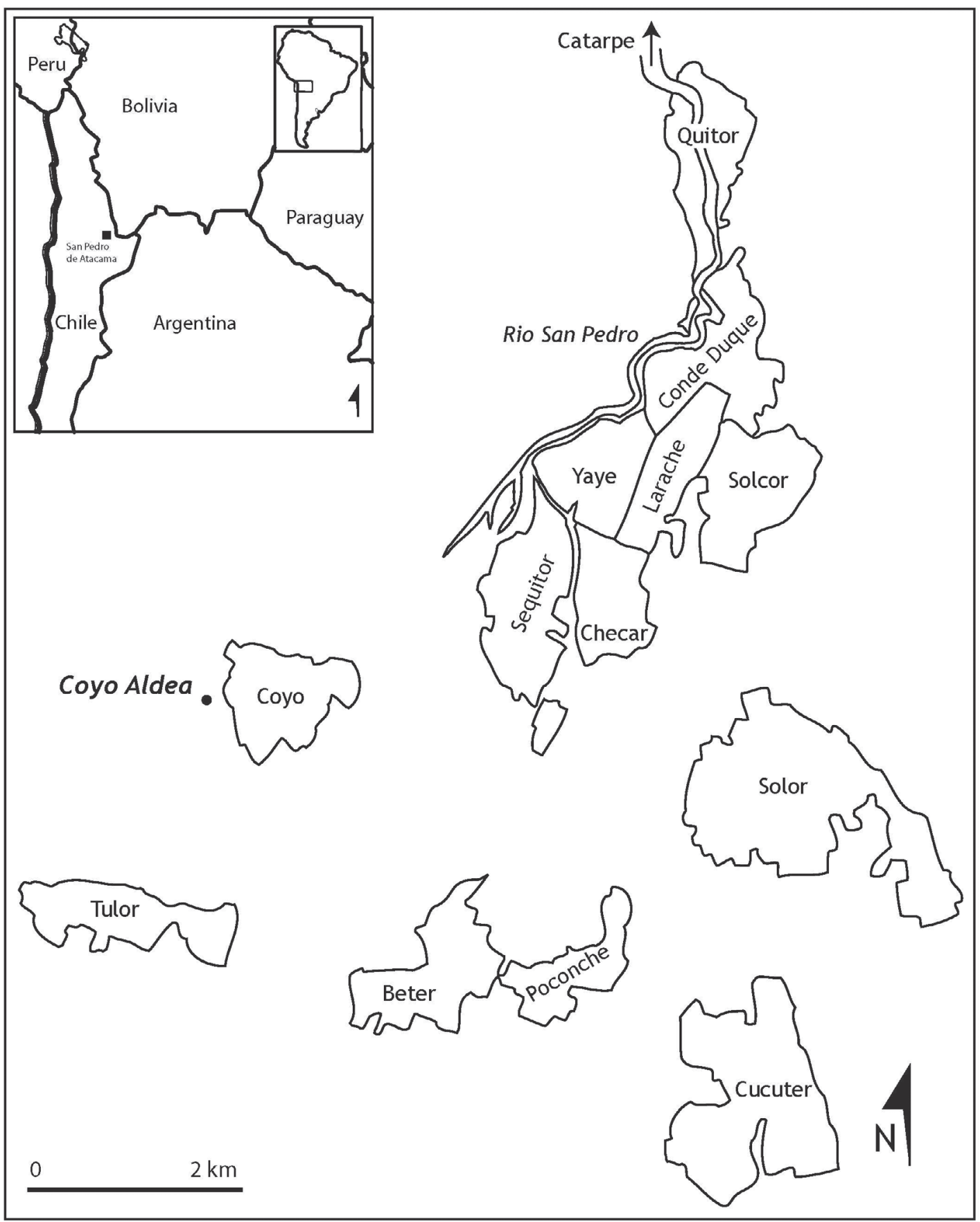

Figure 1. San Pedro de Atacama, location of Coyo Aldea and ayllus (W.T. Whitehead).

San Pedro de Atacama, sus ayllus y la ubicación de Coyo Aldea (W.T. Whitehead).

Agüero and Uribe 2011; Agüero et al. 2006). The Late Formative (AD 100-400) is now seen to be a key moment of local social consolidation which carries with it the refinement of a distinctive polished ceramic tradition that stands out from other contemporary styles, culminating eventually in the iconic Late San Pedro Negro Pulido of the Middle Period (AD 400-950).

Knowledge of Formative Period ceramics (Sinclaire 2004; Sinclaire et al. 1998; Tarragó 
Table 1. Formative and Middle Period chronological phases, San Pedro de Atacama.

Fases cronológicas de los períodos Formativo y Medio, San Pedro de Atacama.

\begin{tabular}{lll}
\hline \multicolumn{1}{c}{ Dates } & \multicolumn{1}{c}{ Period } & \multicolumn{1}{c}{ Phase } \\
\hline 1500-1200 BC & Transition to Formative & Tarajne \\
1200-400 BC & Early Formative & Tilocalar \\
400 BC-AD 100 & Middle Formative & Toconao \\
AD 100-500 & Late Formative & Sequitor \\
AD 500-700 & Middle & Quitor \\
AD 700-950 & & Coyo \\
\hline
\end{tabular}

Sources: Agüero 2005; Agüero and Uribe 2011; Berenguer et al. 1986; Llagostera and Costa 1999; Núñez 1999, 2005, 2006; Núñez and Santoro 2011; Núñez et al. 2006, 2007; Stovel 2013; Tarragó 1989; Torres-Rouff and Hubbe 2013; Uribe 2002, 2006.

1989; Uribe 2006; Uribe and Ayala 2004; Uribe and Vidal 2012) reveals much about of the social dynamics of the Late Formative, but a comprehensive understanding of San Pedro household pottery remains elusive. The polished ceramic tradition that develops after the Middle Formative is prominent in burial contexts and may have had a ritual function there. Is its development contingent on new rituals that are part of these new social changes? Did polished ceramic wares play a role in internal negotiations of power (e.g., Uribe 2004:172, 213)? Does the same elaborate polished style appear in houses and in the same way it appears in graves? Could this suggest increased ritual behavior in domestic and mortuary contexts or do both use mundane household ceramics to draw conceptual parallels between houses, graves, and the afterlife? Data presented here reveal important differences in household ceramics. In fact, dissimilar ceramic practices in the house and in the grave validate more convincingly the ritual role of burial ceramics. This leads us to recommend including local ceramic styles in our comparative analyses of status in San Pedro graves during the Late Formative and Middle Periods.

The current ceramic classification and chronology used in Atacameño archaeology is derived from the impressive collection of funerary ceramics housed at the Gustavo Le Paige Museum (Berenguer et al. 1986; Tarragó 1989; Thomas et al. 1984). Earlier works on domestic ceramics in San
Pedro and surrounding areas are rare (Munizaga 1963; Orellana 1968; Thomas and Benavente 1974-1975) and focused on surface treatment and shape as key organizing principles, much like the contemporary typological system for funerary vessels (e.g., Núñez 1965; Orellana 1963, 1964; Tarragó 1968). Recent regional surveys of residential sites (Agüero 2005; Llagostera and Costa 1999) used this robust funerary classification along with ceramic classes identified systematically at the residential site of Turi in the neighboring upper Loa River Basin (Varela et al. 1993) for chronological and functional site analysis. While much has been gained concerning household ceramic production and Formative ceramic technologies in San Pedro proper from these surveys (Uribe 2006), any significant difference in household types would render site classification and chronological ordering based on funerary ceramic types unreliable (Stovel 2013). In addition, without a more solid and broad understanding of variation in local ceramic production, it is difficult to perceive the sociopolitical changes we attempt to access through ceramic analysis (Uribe 2004:122-136). For these reasons, at least, it is important we query possible differences between household and burial ceramic classes to facilitate deeper discussions of changing production and consumption practices and their social catalysts.

Because shape and color have long been pivotal descriptive attributes used to organize funerary ceramics, the following paper explores these same characteristics in polished ceramic remains obtained from a Late Formative/Middle Period site in San Pedro de Atacama, Chile, near the current ayllu of Coyo (Figures 1 and 2). Polished thinware ceramics were chosen for their comparative potential, as less is currently known about smoothed ceramic traditions from the same time periods (although see Uribe and Ayala 2004 for a larger regional discussion). If household and burial ceramics are obviously different, then the homogeneity and standardization of San Pedro grave ceramics, particularly during the Middle Period (Stovel 2005; Uribe 2004), are more likely to reflect new mortuary practices linked to the increased display of social difference. In particular, clear-cut differences between household and grave ceramics demonstrate a higher likelihood that the latter were used for ritual symbolic ends, and one of these ends might be incipient marking of social differentiation. 


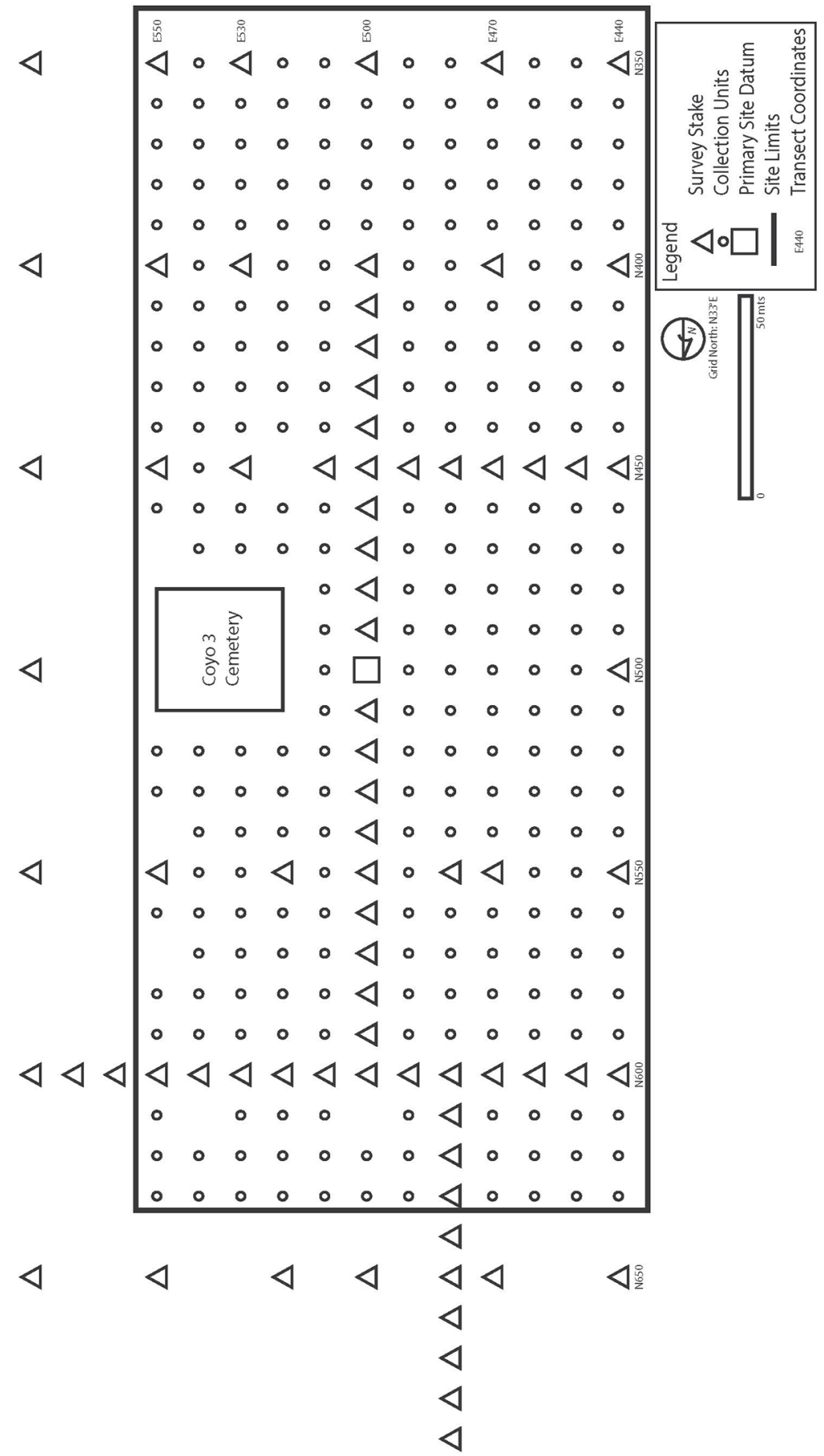




\section{The Late Formative and Early Middle Period Ceramic Evidence}

In addition to growing sedentism and agricultural intensification, the end of the Formative in the Andes is marked by expanding regional trade. New acquisition (and dissemination) of nonlocal goods would have arisen in a social context of growing status differentiation where certain families and/or individuals could display increased access to nonlocal goods and connections with nonlocal peoples in public rituals such as burial, particularly during the Middle Period. We cannot evaluate the possible ritual use of local burial ceramics, however, because we lack a systematic exploration of household ceramics that could prove any unique characteristics given to vessels destined for graves.

Social changes previously seen to characterize the Formative as a whole, such as the consolidation and concentration of populations in the oases, the articulation of these communities with pastoral groups residing in nearby valleys into mutually complementary economic systems, and the formation of villages with agglutinated circular structures, are now seen as particularly characteristic of the Late Formative (Adán and Urbina 2007; Agüero 2005; Agüero and Uribe 2011; Agüero et al. 2006). At the very end of the Formative, communities moved from nearby valleys and more southern locations (Poconche, Cucuter, and Beter, Figure 1) to central areas in San Pedro de Atacama (Tulor and Coyo). Large permanent villages developed, dependent on maize agriculture rather than on earlier small-scale horticultural practices and tree resource exploitation (although see Núñez 2005). And while Middle Formative sites in the oases show a diversity of ceramic styles, Late Formative sites demonstrate a reduced ceramic profile (Uribe 2006:466; Uribe and Ayala 2004). Trade with neighboring areas replaces previous transhumant practices, suggesting changes to the local social organization either engendered by increasing interaction or causing itself a demand for nonlocal ritual goods. One of the key lines of evidence in this process is the narrowing of local ceramic production to focus on a few finely executed ceramic types, both polished and smoothed, for use in tombs.

The Formative and early Middle Period ceramics of northern Chile reveal two types of surface treatment: polished and smoothed (Uribe 2006; Uribe and Ayala 2004). San Pedro polished burial ceramics are robustly studied and provide the groundwork for the chronological phases currently accepted in the area (Table 1; Berenguer et al. 1986; Stovel 2013; Tarragó 1976, 1989; Thomas et al. 1984; Uribe 2002, 2006). Late Formative polished thinware burial styles include Toconao Phase Rojo Pulido jars and Sequitor Phase Negro Pulido vases, bowls, and decorated bottles (Figure 3). Sequitor and Quitor Phase burial ceramics are distinguished by lip form and wall thickness; in the former, lips are straight and walls are slightly thicker, while in the latter lips are slightly everted and walls are thinner (see Types NPIpaV and V vs. NPX and XIII, Figure 3). Household remains, in turn, include polished fragments (Llagostera et al. 1984; Orellana 1988-89), although very few Negro Pulido decorated bottles and undisputable Rojo Pulido remains have been found in household refuse to date (Uribe 2006:470). While household smoothed styles (Loa Café Alisado and Loa Rojo Alisado) have a broader regional distribution (Uribe 2006:458), especially in the early moments of the Formative Period, polished styles (e.g., the aforementioned Rojo and Negro Pulido, and Sequitor Gris-Café Pulido) develop and then define ceramic production in San Pedro and the neighboring upper Loa River Basin (Sinclaire 2004; Sinclaire et al. 1998; Varela et al. 1993) in the Late Formative. As regional studies have revealed, we find that this polished tradition develops as a differentiating characteristic of these communities (e.g., it is rare at sites throughout Tarapacá and Quillagua: Agüero et al. 2006; Uribe and Vidal 2012).

\section{Coyo Aldea}

Polished thinwares from the surface of Coyo Aldea, a Late Formative/Middle Period site located west of the eponymous ayllu (Figures 1 and 2; see also Llagostera and Costa 1999; Núñez 2005) allow us to explore these issues in more depth. Located at S22 57' 18.1" W68 14' 29.8" (Graffam 1995), the site comprises 4 ha of dense ceramic, lithic, and faunal surface deposits overlaying agglutinated adobe circular structures (although a few rectangular structures are also present) immediately adjacent to the Coyo 3 cemetery which dates to the end of the Middle Period (ca. AD 900 with ceramic styles - i.e., Coyo Incised - from the second half of this period; Costa and Llagostera 1994; Munizaga 1963). Coyo 3 is clearly an intrusive element into Coyo Aldea since the latter rests stratigraphically underneath the sand dune that constitutes the matrix of the 

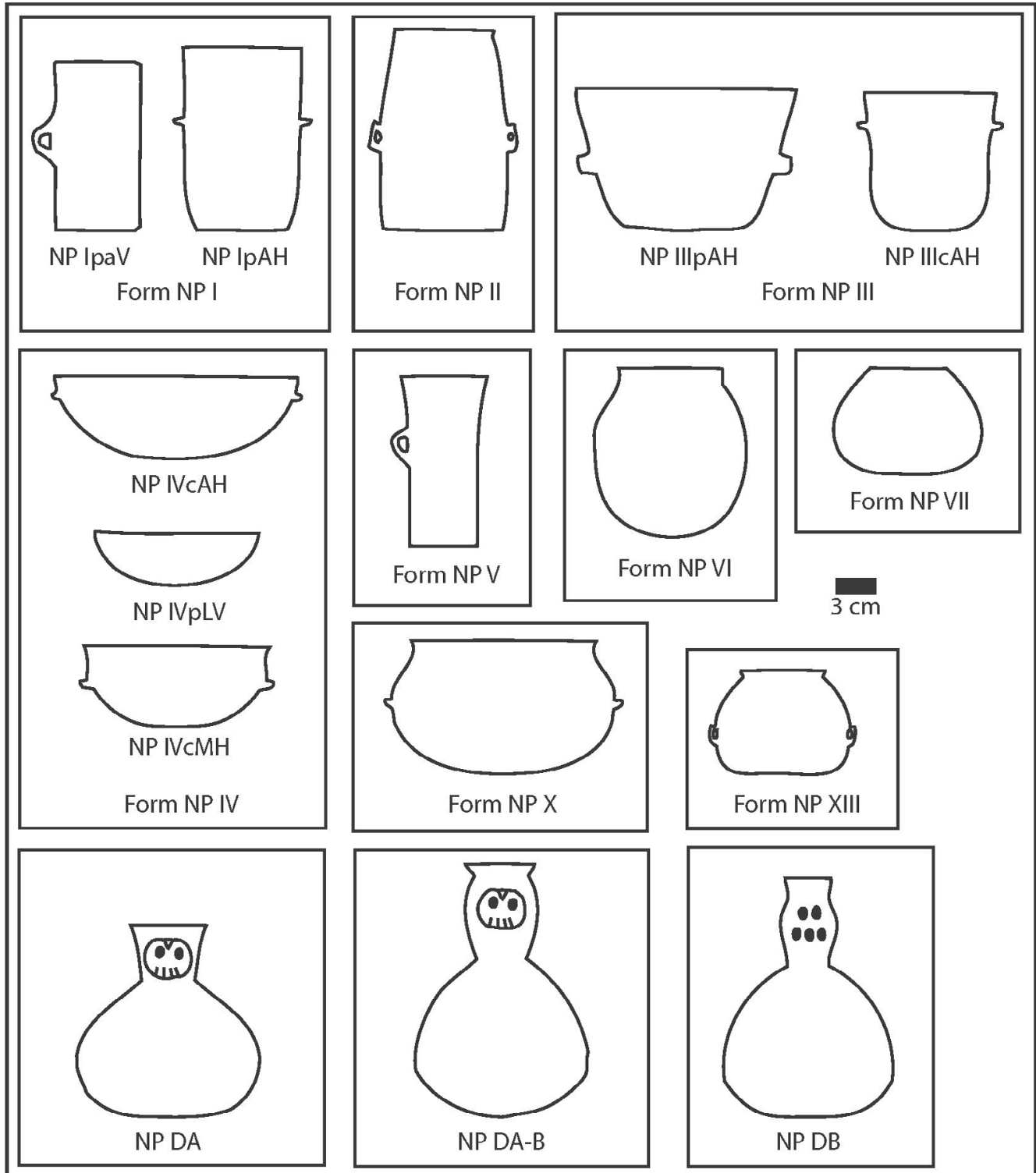

Figure 3. San Pedro Polished Burial Ceramics (redrawn from Tarragó 1989).

Cerámica pulida de tumba, San Pedro de Atacama (re-dibujado de Tarragó 1989).

former (Graffam 1995). Coyo Aldea is more likely contemporaneous with the cemetery Coyo Oriental (Cocilovo and Zavatteri 1994; Cocilovo et al. 2011; Costa et al. 2008; Oakland Rodman 1992).

The chronology for Coyo Aldea was estimated from ceramic analysis (Stovel 1997) and two calibrated radiocarbon dates obtained from test pits (Table 2). The extension and variety of surface ceramic material at the site provides an invaluable source of information on patterns of domestic ceramic production and consumption. Few studies of single sites have been published (although see Llagostera et al. 1984; Orellana 1988-89; Serrancino 1976) therefore this data set is an important opportunity to capture household ceramic characteristics from the entire period of occupation of a village community at a key transitional moment in the region. 
Surface deposits in local residential sites are usually considered separately from subsurface deposits or are thought to post-date the original occupation (e.g., Llagostera et al. 1984; Uribe and Vidal 2012:299). There is evidence, however, that inhabitants of desert environments deposited midden material in unoccupied sectors of their communities such that surface remains correspond to the period of occupation of the entire site (Aldunate 1993; Killion et al. 1989; Lancaster 1986; Lewarch and O'Brien 1981). In essence, abandoned houses filled with garbage and wind-blown sand quite quickly. Lighter sediments were later removed by aeolian processes which compressed deposits and left a thick layer of artifacts distributed across structural remains (Schiffer 1987:239, 243). Spatial clustering of material on the surface of Coyo Aldea confirms this, as do the limited subsurface remains recovered in test excavations conducted at the site (Graffam 1995; Stovel 1997). Observations extrapolated from surface finds should pertain to the site as a whole, however, not to the residential structures found immediately below them.

The material collected from the site's surface represents a $1 \%$ sample of the study area (Figure 2). Diagnostic ceramic fragments were selected according to both shape and surface treatment. We cannot know how much of the surface deposits was lost to wind and erosion since the site's abandonment, but ceramic fragments are less likely to move very far as they are heavier. Surface erosion is much more common and small fragments were excluded from this study as a result. That said, polished thinwares are recognizable from wall thickness and lip forms that are not shared with smoothed vessels at this time period, even if their luster is not as prominent after years of exposure. In addition, the entire data set was impacted equally so data loss to wind erosion would not selectively influence one sector of the study area over any other. Finally, only the top layer of surface remains was impacted by wind erosion and sand ablation. The majority of the collection was recovered slightly below the desert pavement which, hardened through wind compaction, protected most of the material remains on the site's surface.

We report here on the polished thinwares relevant to funerary classifications, but the original ceramic analysis (which sought to understand the chronology of the site) included other diagnostic types. In this previous study (Stovel 1997), a the total of 728 sherds examined included 257 (35\%) fragments classified as "smoothed utilitarian", 15 classified as Los Morros (an Early to Middle Formative ceramic type with large angular inclusions, Uribe 2006, and 4 identified as nonlocal (Vaquerías or Candelaria). Similar nonlocal ceramics have been found in other contemporaneous residential contexts (Agüero and Uribe 2011).

\section{Sample Collection and Analytical Methods}

Coyo Aldea was sampled at standard intervals to ensure coverage of the most densely covered portion of the 3 ha artifact scatter $(280 \mathrm{~m} \times 110$ m, Figure 2). A $10 \times 10 \mathrm{~m}$ grid was marked with wooden stakes and at the intersection of every transect, a $1 \times 1 \mathrm{~m}$ unit was cleared of all cultural material found on or just below the surface. Stakes used for surveying and elevation stations were cleared of cultural material in a circular radius of $2 \mathrm{~m}$. Surface sand and debris were collected and screened. Artifacts were placed in a bag labeled with a bag number. Thirty bags were collected outside of the sampling area to evaluate the dropping off of material densities at the site's edge. Material counts were conducted in 4 transects due north, south, east,

Table 2. Radiocarbon dates for Coyo Aldea.

Fechas radiocarbónicas para Coyo Aldea.

\begin{tabular}{|c|c|c|c|c|c|c|}
\hline Sample \# & Unit & $\begin{array}{l}\text { Depth } \\
\mathrm{cm}\end{array}$ & $\begin{array}{c}\text { Sample } \\
\text { Material }\end{array}$ & $\begin{array}{c}\text { Conventional } \\
\text { Date }\end{array}$ & $\begin{array}{l}\text { Calibrated } \\
\text { Date* }\end{array}$ & Intercept \\
\hline Beta - 94113 & N430E469 & $75-80$ & Wooden post & $1,710+60 \mathrm{BP}$ & AD $220-450$ & AD 370 \\
\hline Beta - 94114 & N608E543 & $5-10$ & Charcoal & $1,220+80 \mathrm{BP}$ & AD 660-995 & AD 795 \\
\hline
\end{tabular}

* Calibration of $95 \%$ probability for 2 sigma, Beta Analytic.

Sources: Stovel 1997, see also Núñez 2005. 
and west to confirm the same. This established site limits and density minimums. In all, 614 bags were collected, inventoried, and are stored in the Museo Arqueológico R. P. Gustavo Le Paige in San Pedro de Atacama (IIAM-UCN).

The data presented here involve the comparison of household rim types with known burial forms, an examination of the patterning in distribution of these rim types across the site's surface, and the quantification of color variation. The rim was defined as the last $2 \mathrm{~cm}$ of the vessel and fragments smaller than $3 \mathrm{~cm}^{2}$ were excluded. Fragments were organized according to shape, surface treatment, diameter, and thickness (Table 3) in an effort to tie household evidence to known typologies established in burial studies. Rim and lip configuration (Figure 3) is diagnostic of vessel shape categories identified by Tarragó (1989; i.e., straight, everted, or inverted lip with straight, constricted, or outward flaring rim).

Rim and lip configurations could thus be associated with known vessels forms, reveal unusual or new vessel types, and be assigned TL dates from similar burial forms provided by Berenguer and his colleagues $(1986 ; 1988)$. Classification according to known vessel form was not always straightforward because even though diameter averages are provided for burial types (Tarragó 1976), there is evidence that burial contexts receive a larger frequency of miniature vessels (Agüero 2000; Cases et al. 2008; Costa and Llagostera 1994; Uribe 2002; for the Andes in general see Isbell 2004; López 2013; Shimada et al. 2004). Moreover, Coyo Aldea rims did not always show multimodal diameter distributions suggestive of the size categories found in graves. Surface types were divided by arbitrary diameter ranges to highlight their variability and the preponderance of high values in the sample. An uneven distribution of rim types across the site's surface would reveal possible chronological relationships.

To ensure our color analysis was independent and representative of the surface population, a randomized selection of bags was performed from which a new sample of polished sherds was extracted. This selection process involved dividing the site map into four sectors to ensure equal representation of the entire area. Twenty percent of bags from each were selected through random number generation, providing a stratified sample of 3,433 polished sherds for color analysis. Compositional and mineralogical analyses of thinwares from this sample appear elsewhere (see Echenique 2012; Stovel et al. 2013).
Both rim and color analyses are presented below and provide a picture of the household ceramic world of Coyo Aldea and San Pedro de Atacama between $\mathrm{AD} 100$ and 700.

\section{Ceramic Analysis Results}

\section{Shape analysis: assigning known forms to rim types}

Shape analysis from Stovel's (1997) original study included smoothed and incised remains, but the data presented here focus on polished sherds to allow us to focus on the development of this distinctive ceramic tradition during the Late Formative. Table 3 presents the range of rim types with polished surfaces (interior and/or exterior) recovered and their possible burial equivalent. Types A, B, C, D, F and G are the most useful to our present analysis. Most other types fall within Tarragó's (1989) broad category of open bowls, Form NP IV ${ }^{1}$ (Figure 3), which characterizes all periods of polished ceramic production.

Type A fragments (Figure 4) correspond to burial Form 1 (Figure 3) which includes an earlier thick-walled variant (IpaV, Coyo Aldea Type A2) and later, thin-walled, more highly polished variants (IpzV and IpAH, Coyo Aldea Types A1 and A4). Tarragó (1989) and Berenguer and colleagues (1986; 1988) used thermoluminescence (all the dates in this paragraph are TL) to date these variants to AD $90 \pm 200$ and $230 \pm 160$ respectively. The earlier variant appears in graves with Rojo Pulido during the Toconao Phase while the later variants occur with large bowls during the Sequitor Phase (Tarragó 1989:383-384). Type B fragments correspond to burial Form II that includes a short variant with a smaller mouth diameter corresponding more likely to Coyo Aldea Type D1. Tarragó's (1989:42-43, 386-387; Berenguer et al. 1986:34) Form II is dated to AD $720 \pm 95$ and appears in graves with associations characteristic of the Sequitor and Quitor Phases. Type C fragments can be tied to burial forms XIII and X. These are two sizes of small casseroles or pots typical of Quitor Phase graves $^{2}$ (Tarragó 1989:386). The range of diameters for this rim type is much larger than those found in burials (e.g., Tarragó 1976:44). Coyo Aldea Type F coincides with burial Form $\mathrm{V}$ which, although not dated directly itself, is found in graves with Form $\mathrm{IpaV}$ from the end of Toconao or the beginning of 


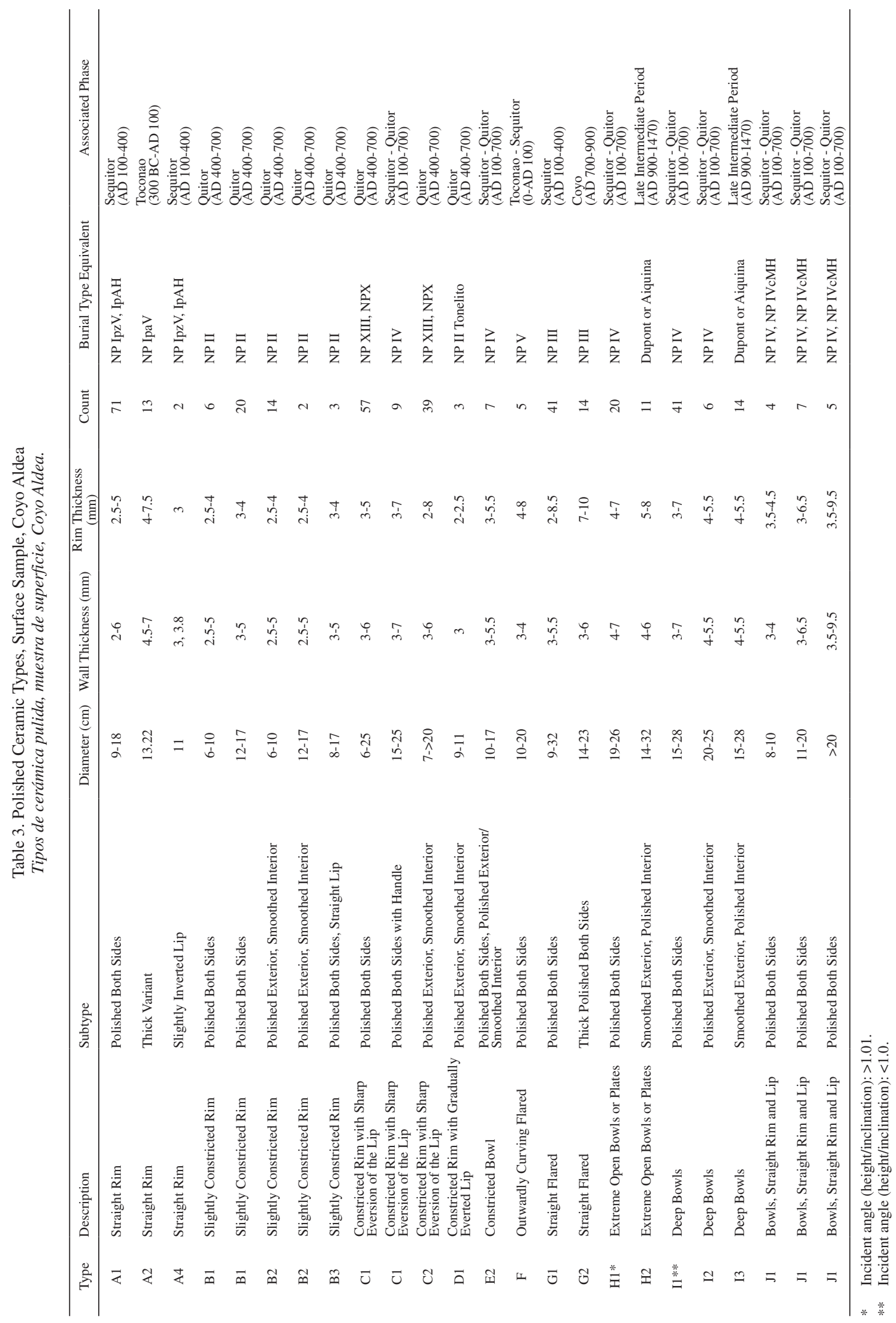



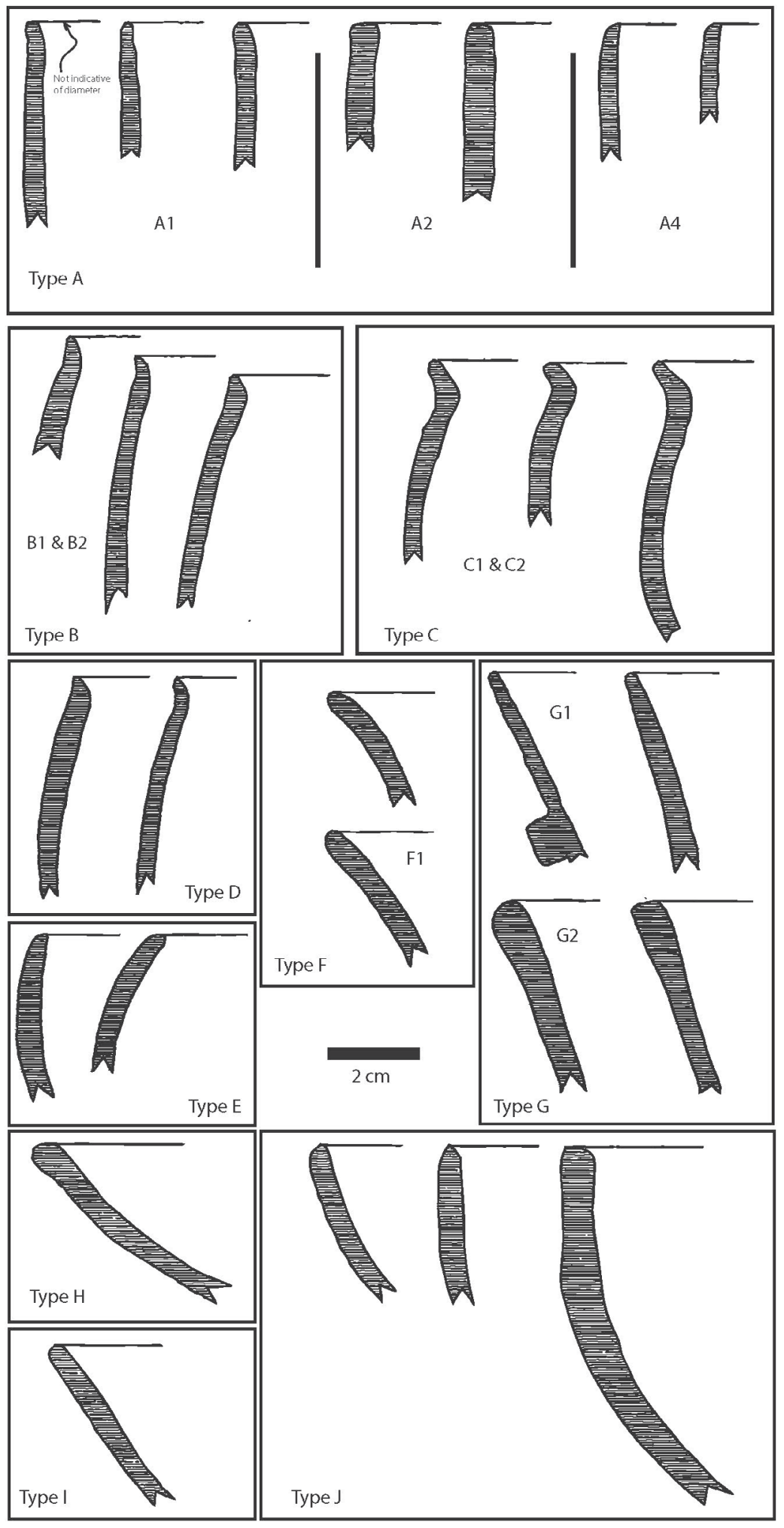

Figure 4. Coyo Aldea Rim Types (source: Stovel 1997).

Tipos de borde, muestra cerámica Coyo Aldea (fuente: Stovel 1997). 
Sequitor Phases as outlined above. Finally, Type $\mathrm{G}$ reflects Form III which has two variants. These include, much like Form I, an earlier wider thickwalled version (Form IIIpAH) associated with ceramic forms from the second half of Toconao and the first half of Sequitor Phases, and a taller, narrower, thin-walled variant dated to the second half of Sequitor (Tarragó 1989:43, 381). Specific TL dates for Form III are AD 140 $\pm 150,325 \pm 190$, and 560 \pm 145 (Berenguer et al. 1986).

Material from the surface of Coyo Aldea coincides with materials from the Early Formative to the Late Intermediate Period, but most diagnostic styles date to Toconao, Sequitor and Quitor Phases (ca. $300 \mathrm{BC}$ to AD 700; Figure 5). The most numerous styles found on the surface of Coyo Aldea are from Sequitor and Quitor Phases, while fragments pertaining to earlier Toconao or later Coyo Phases are less frequent. These date ranges are corroborated by absolute dates provided by an excavated wooden post and charcoal from two test pits (Table 2; Graffam 1995; Núñez 2005; Stovel 1997). The most frequent forms are tall straight-sided cups or vases, short constricted pots and casseroles, and open bowls.

\section{Spatial analysis: exploring the distribution of rim types across the site's surface}

In order to cross-check chronological interpretations provided here and elsewhere (e.g., Agüero et al. 2006; Tarragó 1989) and sustain the assumption that surface materials date to the principal occupation of the site, surface concentrations were identified to compare their ceramic profiles and determine any differences in the spatial distribution of rim types. Figure 2 and Table 4 lists these areas as Zones A, B, and C (see also Stovel 1997). The presence of spatial clustering of material on the site's surface suggests these deposits were not the product of random dumping, but rather represent accumulation in abandoned sectors of the site. Significant differences in the material recovered from these concentrated artifact clusters would further sustain this argument.

All but Coyo Aldea Rim Types A1, B, C1, and $\mathrm{G}$ show even distribution among the three sectors (Table 4) or such low frequencies that cannot be compared across the site. Within these four, A and $\mathrm{C}$ are inversely correlated spatially. More than half the fragments of A1 are found in Zone A while C1

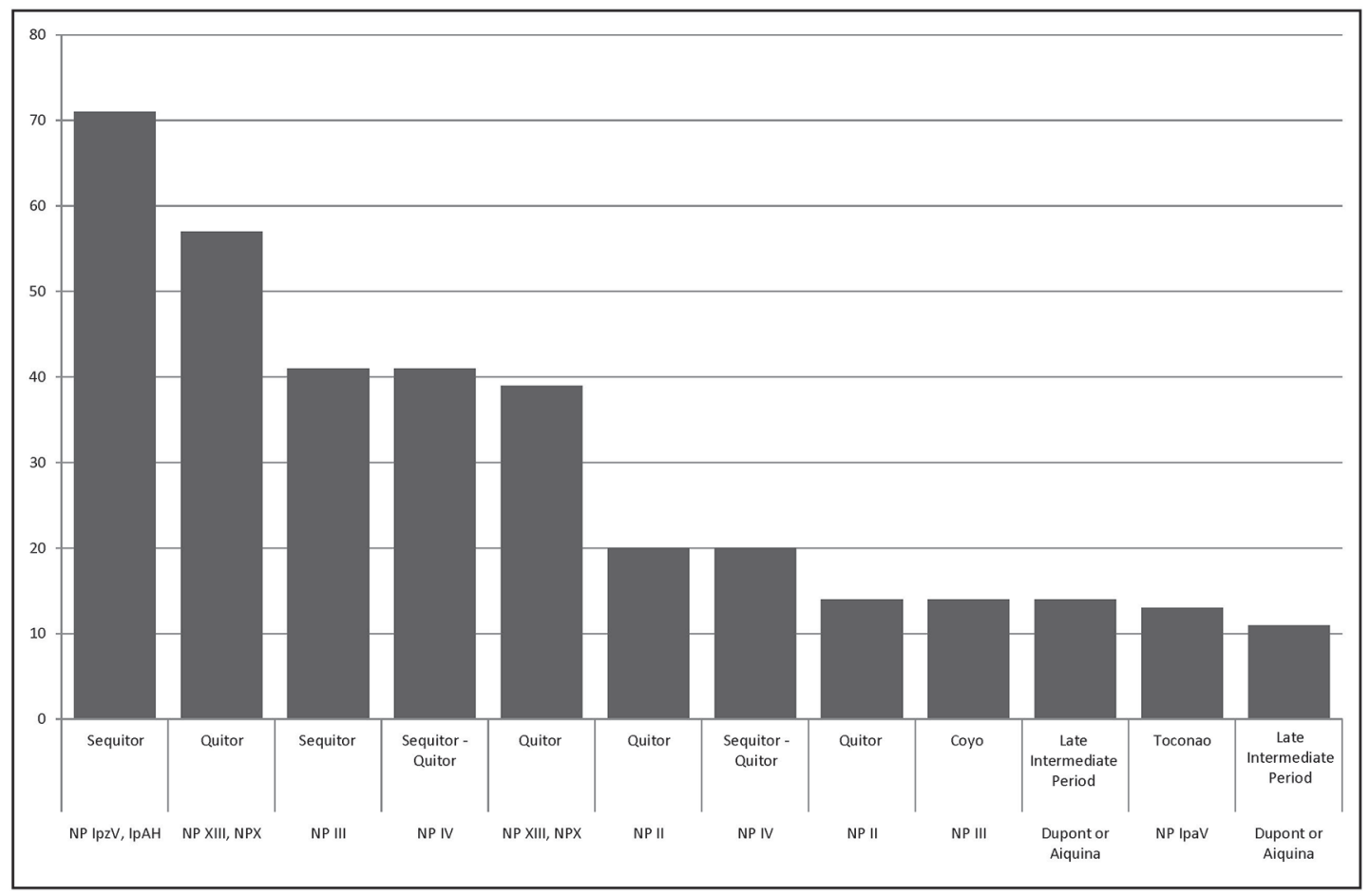

Figure 5. Frequency Distribution of Coyo Aldea Rim Types (W.T. Whitehead).

Frecuencia de los tipos de borde, muestra cerámica Coyo Aldea (W.T. Whitehead). 
Table 4. Spatial distribution of Coyo Aldea rim types.

Distribución espacial de los tipos de borde de Coyo Aldea.

\begin{tabular}{lrrrr}
\hline \multicolumn{1}{c}{ Type } & Zone A & Zone B & Zone C & Total \\
\hline A1 & 53 & 14 & 4 & 71 \\
A2 & 4 & 2 & 2 & 8 \\
A4 & 1 & 0 & 0 & 1 \\
B1 & 14 & 2 & 9 & 25 \\
B2 & 9 & 0 & 10 & 19 \\
B3 & 0 & 0 & 2 & 2 \\
C1 & 13 & 10 & 32 & 55 \\
C2 & 10 & 6 & 21 & 37 \\
D & 1 & 0 & 2 & 3 \\
E & 1 & 0 & 3 & 4 \\
F & 3 & 0 & 2 & 5 \\
G1 & 22 & 5 & 7 & 34 \\
H1 & 9 & 7 & 2 & 18 \\
H2 & 1 & 2 & 6 & 9 \\
I1 & 17 & 8 & 10 & 35 \\
I2 & 1 & 3 & 1 & 5 \\
I3 & 4 & 0 & 8 & 12 \\
J1 & 6 & 6 & 3 & 15 \\
J2 & 0 & 2 & 2 & 4 \\
\hline Totals & 169 & 67 & 126 & 362 \\
\hline
\end{tabular}

and $\mathrm{C} 2$ are more likely from Zone C. Interestingly, $\mathrm{B} 1$ is found principally in Zone $\mathrm{A}$, and $\mathrm{B} 2$ is found in both A and C. As B2 fragments have smaller diameter and no polished interior, they represent more constricted variants of the form. Rim Type A corresponds to burial types from Toconao or Sequitor Phases while Rim Type $\mathrm{C}$ reflects burial types from Quitor Phase. While no data is provided here that would allow us to confirm that household fragments date to the same time periods as their equivalents found in graves, the same inverse correlation is found in graves (Tarragó 1989). Forms I and XIII/X are rarely found together in graves and appear to be mutually discrete in household refuse too. This evidence confirms the chronological significance of straight versus everted rim shapes. Polished vessels during the Sequitor Phase (i.e., Late Formative Period) display straight lip and rim configuration, while polished vessels during Quitor (i.e., early Middle Period) reveal a sharp eversion of the lip from a more constricted vessel. This is a useful chronological marker for future archaeological work in the area. Chi-square analysis confirmed the statistical significance of these results (Stovel 1997).

\section{Color analysis: understanding the frequency of color variation in the sample}

A new stratified random sample of the recovered ceramics allowed us to study color variation systematically. Polished fragments display a range of colors (black, gray, brown and red; see Table 5) both alone and in combination on one sherd, but black (45\%), gray (19\%), and brown (12\%), are the most frequent (Figure 6). Gray/Black (with either on the interior or exterior of the sherd) is the most common combination at (11\%). In a comparison of surface color and paste color (as proxy for firing conditions), we find (Figure 7) that black wares are generally fully reduced, graywares are either fully reduced or incompletely reduced, while brownwares are almost always fully oxidized with infrequent cases of incomplete oxidation. Brownwares seem to have been produced as intentionally oxidized burnished ceramic vessels while blackwares are almost always the product of reduced conditions. It is difficult, therefore, to determine whether graywares were an intentional color category that resulted from specific production practices or whether they were the product of error in the reduction process. The larger proportion of sherds with black and gray in combination suggests that these colors were the product of the same production process. Finally, gray sherds may be fragments of vessels with gray and black areas, but the same cannot be said of brownwares. These would have been produced through a discrete firing process.

An examination of sherd wall thickness is also relevant here (Figure 8). The three ware types present a homogeneous range of thicknesses, but graywares, while they share similar wall thicknesses to black and brown sherds, have a tendency toward thicker walls. Perhaps the thinner variants represent a subset of blackwares produced through imperfect reduction practices, while thick-walled variants constitute a different category, the Negro "Casi" Pulido or Gris Grueso Pulido (Le Paige 1964, 1977; Tarragó 1976, 1989), although there is considerable overlap in wall thickness among all three ware types.

It is important to note the conspicuous rarity of bottle fragments (especially those with anthropomorphic faces), a vital burial good for some ayllus in prehistory, and of nonlocal sherds, including the absence of Tiwanaku ceramics (Stovel 1997). Only four polished bottle fragments were recovered, including one gray, two black, and one 


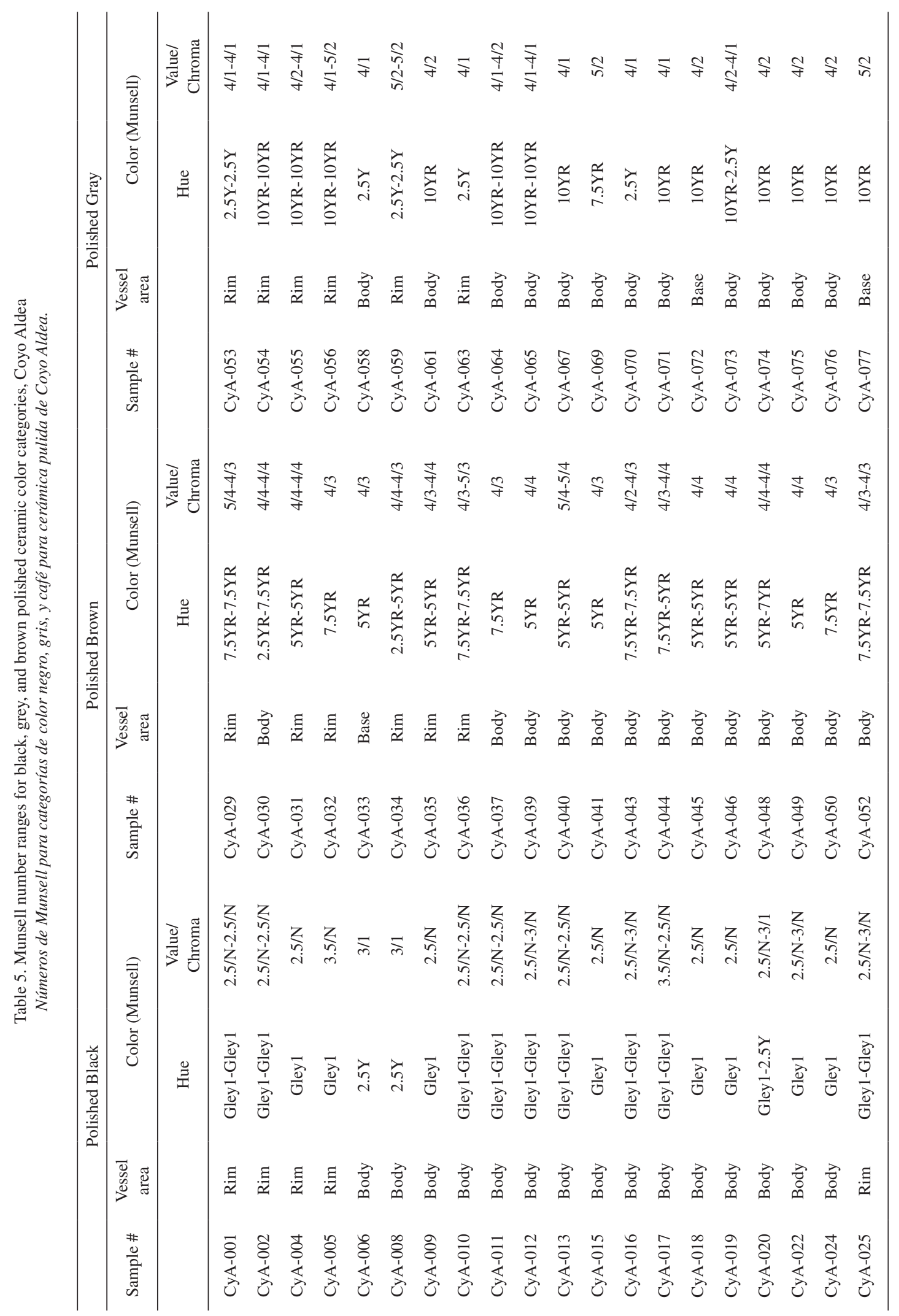




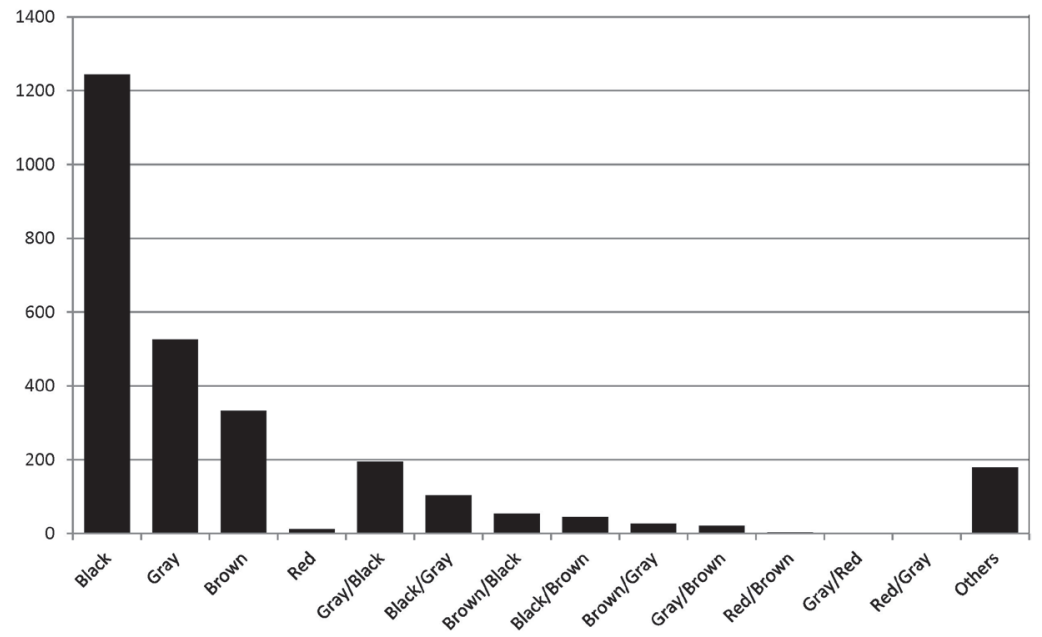

Figure 6. Coyo Aldea, polished fragment color distribution (source: Echenique 2012). Variabilidad de colores de cerámica pulida, Coyo Aldea (fuente: Echenique 2012).

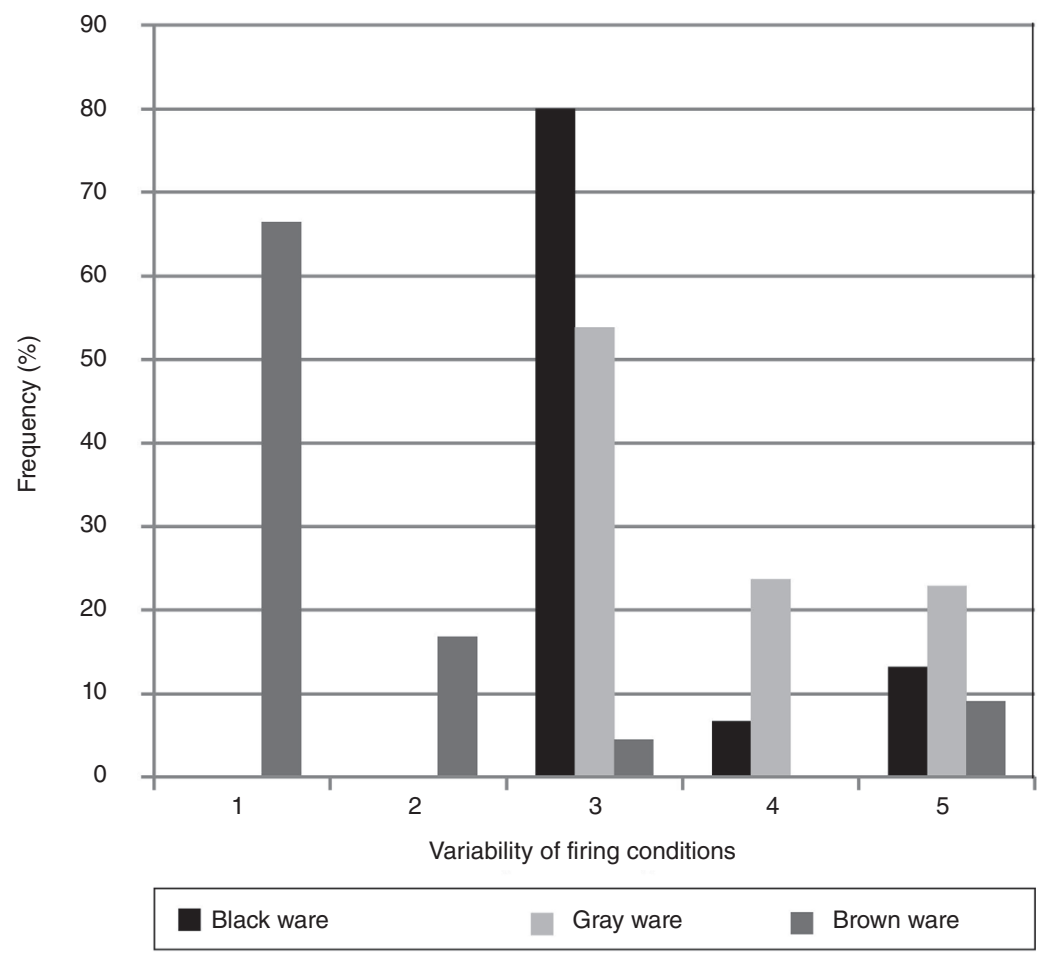

Figure 7. Frequency of firing conditions (based on paste color) by surface color (source: Echenique 2012). 1=complete oxidation, clear color, $2=$ incomplete oxidation, with black core $3=$ reduced/smudged, dark gray or black, $4=$ superficially smudged, dark gray or black with clear core, $5=$ incomplete reduction, irregular colors.

Condiciones de cocción (basado en color de las pastas) por color de superficie (fuente: Echenique 2012). 1=oxidación completa, color claro, 2 =oxidación incompleta, núcleo oscuro, $3=$ reducción/ahumado, color oscuro, $4=$ superficie ahumada, color oscuro con núcleo claro, $5=$ reducción incompleta, color irregular. 


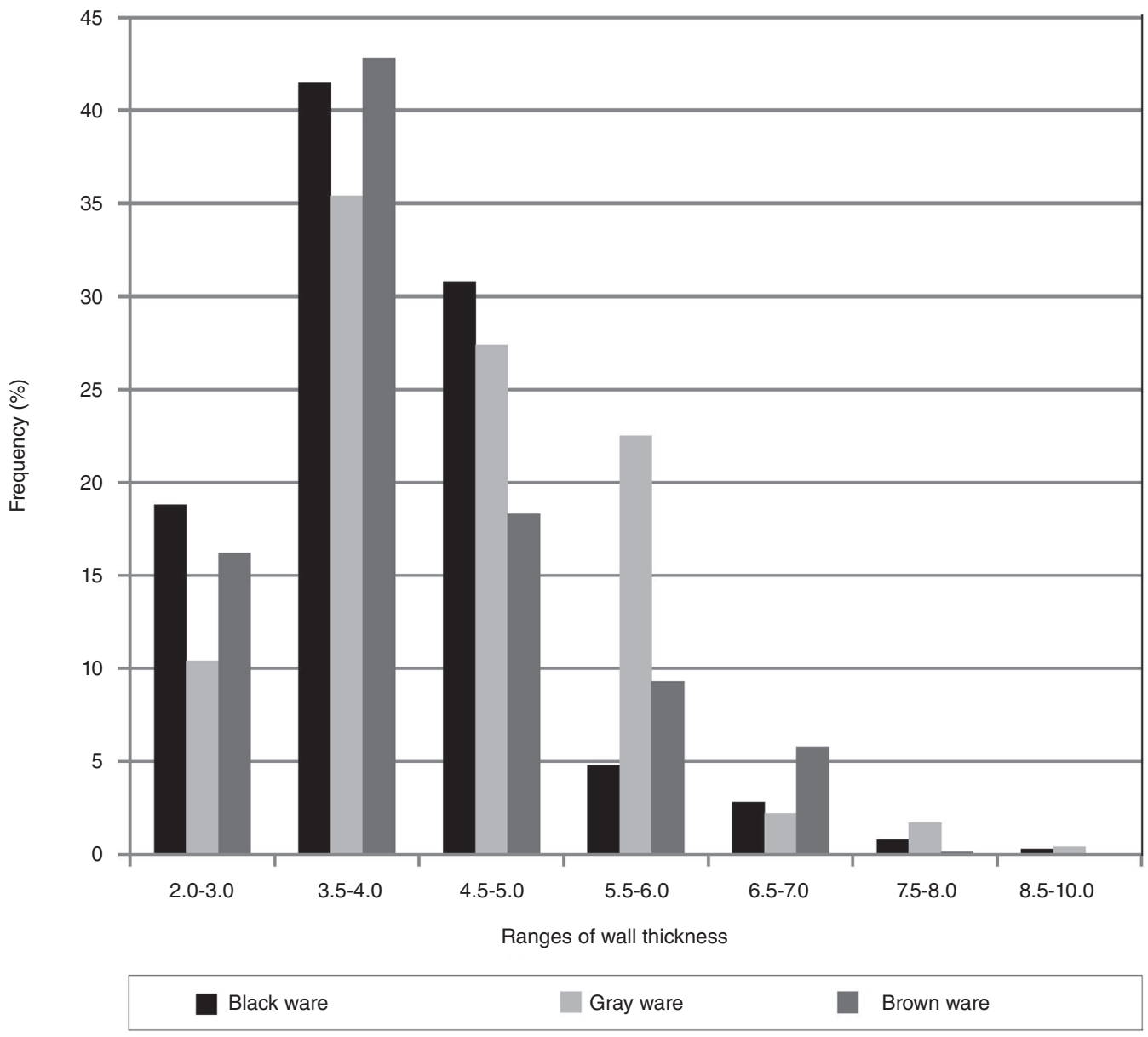

Figure 8. Frequency of ranges of wall thicknesses among color categories (source: Echenique 2012). Espesores de pared por color de superficie (Fuente: Echenique 2012).

brownware example. It is possible that some ovoide body fragments originated in bottles, but the rarity of neck portions confirms the designation of bottles as primarily grave goods. Three incised Candelaria fragments and one Vaquerías fragment were found in the surface collection, echoing the styles and quantities of other Late Formative sites in the area (Agüero and Uribe 2011; Llagostera et al. 1984; Uribe 2006). No Tiwanaku sherds were recovered, although many styles in the collection date to the Middle Period. It is likely that Tiwanaku materials were incorporated into local graves rather than household contexts, or they were not discarded with household refuse.

\section{Late Formative and Middle Period Household Pottery in San Pedro}

If household ceramics can be linked directly to dates published for burial ceramics (which themselves may be under slight adjustment; Stovel 2013), then Coyo Aldea does appear to have been subject to midden dumping by village residents during the Late Formative and Middle Periods. The surface sample recovered from Coyo Aldea suggests that household contexts were characterized by vessels with larger diameters and higher color variation that those found in burials and that these differences were the product of intentional production practices. While shapes are shared by houses and graves, items in houses do not need to have consistently black polished surfaces (although these are the most common types of polished ceramics found at this site). Household blackwares are clearly more variable in their color, suggesting that the few graywares found in graves might be household variants of blackwares rather than a chronologically discrete group. No evidence of redwares or Rojo Pulido was recovered, although the brownwares described here might represent brown 
fragments of this highly variable ceramic style. Most of the non-gray or non-blackware fragments were clearly brown rather than orangey red, therefore it is likely that they correspond to oxidized variants of blackware shapes found in graves, as described by Sinclaire and colleagues (1998; Sinclaire 2004), rather than fragments of the discrete redware style.

Although it cannot be demonstrated definitively from the present data, bowls (restricted and unrestricted) seem to make up a large proportion of polished vessels in household contexts, followed by tall narrow vessels. In this way, serving and drinking are well represented in the household sample studied here. Ceramic production that developed in the Late Formative seems to have distinguished between a ritual burial suite of artefacts that includes anthropomorphic bottles, small thinware pots and cups, and redware jars, and a household suite of objects that emphasized larger black and brown casseroles, pots, and cups. The lack of activity areas or occupation surfaces excavated from residential sites prevents our discussion of different behaviors linked with these forms (i.e., communal feasting practices). Burial contexts feature a discrete set of objects, but we should not consider all burial ceramics to have had the same meaning or representative roles. Some vessels found in graves may have functioned as 'mundane' serving vessels for the dead, while others might have conveyed wealth, and/or status, or other meanings. Thus, we do not argue for a binary opposition of household and burial ceramic consumption, but suggest San Pedro burial ceramics display more homogeneous colors and more standardized size classes, reflecting a ritual and symbolic role through an exaggerated and essentialized aesthetic (rather than assuming this to be the case a priori).

While a clear goal of this study is to provide a more complete picture of ceramic variability produced by the ancient communities of San Pedro, this variability contributes to the study of social complexity in the future by adding confidence to our inferences suggesting the ritual role of burial ceramics. Larger Andean discussions of the Formative highlight the role of ritual and nonlocal goods in new negotiations of power through the adoption of already meaningful symbols in new ways. The iconographic and material maintenance of power and status, therefore, is internally referential (Hastorf 2008; Roddick and Hastorf 2010). In the moments of change that characterized the latter part of the
Formative, for example, traditions were reworked, rethought or explicitly reinforced. Public architecture, communal feasting, the marking of ancestors and eventually political figures, when examined diachronically, take advantage of qualities found in previous symbols and concepts (e.g., Janusek 2006; Potter and Perry 2011). Although nonlocal goods and materials are important as prestige goods, local craft production, its intensification and control by new elite individuals or families, can be an equally important avenue for displays of status and wealth accumulation in smaller-scale communities (Vaughn 2006). Growing social complexity may explain the massive production of a highly standardized ceramic by numerous households (Uribe 2004:213) given the lack of larger-scale ceramic production centers identified in the region. This is not unusual given that "many of the crafts that were developed in the Andes, while having utilitarian 'functions', appear to have been used primarily as prestige goods and to depict elaborate motifs that served to validate emerging status differences" (Vaughn 2006:317). It is equally possible that this enhanced production served the export of ritual vessels, since so many Negro Pulido vessels found outside San Pedro proper are burial forms (Fernández 1978; Llagostera et al. 1988; Tarragó 1984, 2006), although residential sites with Negro Pulido ceramics in southern Bolivia warrant future study (Nielsen et al. 1999). Polished thinware production in Late Formative and Middle Period San Pedro distilled, exaggerated, and standardized the aesthetic of vessels found in houses, in addition to producing vessel shapes unique to burials. These qualities were very likely harnessed to differentiate among interred people between and within ayllus (Uribe 2004:208-214, see also Nado et al. 2012; Torres-Rouff et al. 2013).

\section{Conclusion}

The data presented here sought to explore the ceramic world of San Pedro de Atacama, northern Chile, by contributing a new household sample to the discussion. Most of the diagnostic rims from the Coyo Aldea collection correspond to vessel shapes from the funerary phases Sequitor and Quitor (ca. AD 100-700). The collection exhibits ceramic variation absent in graves, including a wider range of colors and larger diameters. It also lacks the breadth of nonlocal ceramics found in graves (Stovel 2008) and Tiwanaku vessel remains. We 
cannot contribute to persistent questions concerning the chronological coincidence of household and burial ceramic styles here, but we do expand our typological knowledge to include new color and size variation generally exclusive to houses which also tend to include larger serving vessels, rather than small bottles. Polished black ceramics are common in household refuse, but they are more likely to be variable in color, larger in diameter, and to be a casserole or cup, rather than a bottle. It would appear that much of the grayware identified at Coyo Aldea is a variant of blackware, the product of incomplete reduction or smudging. There is also an oxidized brownware variant of the polished blackware. Redware is essentially absent. These same wares were found in houses in the upper Río Loa Basin (Sinclaire 2004; Sinclaire et al. 1998).

For the Late Formative and early Middle Period, burial ceramics are explicitly black or red, standardized in shape, size, and color, and include a range of vessel shapes not found in houses. It is tempting to propose that ritual ceramics, high in quality and discrete in style and form, represented an important part of new elite identities that developed after contact with Tiwanaku (Berenguer and Dauelsberg 1989). Vessel standardization, however, declines throughout the Middle Period (Stovel 2005) and perhaps a need for a new burial ceramic style in the Late Formative, corresponding to social changes that predate interaction with Tiwanaku, actually sparked this distinctive polished tradition. We are prompted to look at the use of local craft production to redefine status in graves earlier in prehistory than previously thought.

Acknowledgements: We would like to thank Gray Graffam, Lautaro Núñez, Yorka Crespo, and Francisco Téllez for facilitating the completion of the original surface collection and ceramic analysis at Coyo Aldea, the staff and academics of the Instituto de Investigaciones Arqueológicas y Museo Gustavo Le Paige (IIAM-UCN), and William T. Whitehead for indispensable help. The authors also thank the Anillos ACT-96 Project "Interacciones y movilidad humana en poblaciones prehispánicas del Norte de Chile: Una Aproximación desde las ciencias sociales usando marcadores biomédicos, químicos y mineralógicos", which partially funded the analyses presented here. Additional support was provided by a Tinker field research grant, a Reicker grant, the Emil W. Haury Education Fund for Archaeology, a William and Nancy Sullivan Scholarship, and BecasChile (CONICYT). Careful comments from three anonymous reviewers guided our revision process and we thank them for their time and consideration.

\section{References Cited}

Adán, L., and S. Urbina 2007. Arquitectura formativa en San Pedro de Atacama. Estudios Atacameños 34:7-30.

Agüero, C. 2000. Fragmentos para armar un territorio. La textilería en Atacama durante los períodos Intermedio Tardío y Tardío. Estudios Atacameños 20:7-28.

Agüero, C. 2005. Aproximación al asentamiento humano temprano en los oasis de San Pedro de Atacama. Estudios Atacameños 30:29-60.

Agüero, C., and M. Uribe 2011. Las sociedades formativas de San Pedro de Atacama: Asentamiento, cronología y proceso. Estudios Atacameños 42:53-78.

Agüero, C., P. Ayala, M. Uribe, C. Carrasco, and B. Cases 2006. El período Formativo desde Quillagua, Loa Inferior (norte de Chile). In Esferas de Interacción Prehistóricas y Fronteras Nacionales Modernas: los Andes Sur Centrales, edited by H. Lechtman, pp. 73-120. Instituto de Estudios Peruanos and Institute of Andean Research, Lima.

Aldunate, C. 1993. Arqueología en el pukara de Turi. Actas del XII Congreso Nacional de Arqueología Chilena. Boletín del Museo Regional de la Araucanía 2:61-78.
Baker, J.L. 2012. The Funeral Kit: Mortuary Practices in the Archaeological Record. Left Coast Press Press Inc., Walnut Creek.

Berenguer, J. and P. Dauelsberg 1989. El Norte Grande en la órbita de Tiwanaku. In Culturas de Chile. Prehistoria: Desde sus Orígenes hasta los Albores de la Conquista, edited by J. Hidalgo, V. Schiappacasse, H. Niemeyer, C. Aldunate, and I. Solimano, pp. 129-180. Andres Bello, Santiago.

Berenguer, J., A. Deza, A. Roman, and A. Llagostera 1986. La secuencia de Myriam Tarragó para San Pedro de Atacama: un test por termoluminiscencia. Revista Chilena de Antropología 5:17-54.

Berenguer, J., A. Roman, A. Deza, and A. Llagostera 1988. Testing a cultural sequence for the Atacama Desert. Current Anthropology 29:341-346.

Cases, B., C. Rees, G. Pimentel, R. Labarca, and D. Leiva 2008. Sugerencias desde un contexto funerario en un "espacio vacío" del desierto de Atacama. Boletín del Museo Chileno de Arte Precolombino 13:51-70.

Cocilovo, J., and M. Zavattieri 1994. Biología del grupo prehistórico de Coyo Oriental (San Pedro de Atacama, norte de 
Chile): II. Deformación craneana artificial. Estudios Atacameños $11: 135-144$

Cocilovo, J.A., A. Llagostera, and H.H. Varela 2011. Armando el rompecabezas en San Pedro de Atacama: el sitio Coyo Oriental y la cuestión de los sectores del Padre Le Paige desde la antropología biológica. Revista Chilena de Antropología 23:149-172.

Costa, M.A., and A. Llagostera 1994. Coyo-3: Momentos finales del período medio en San Pedro de Atacama. Estudios Atacameños 11:73-107.

Costa, M.A., A. Llagostera, and J.A. Cocilovo 2008. La deformación craneana en la población prehistórica de Coyo Oriente, San Pedro de Atacama. Estudios Atacameños 36:29-41.

Echenique, E. 2012. Ceramic Production in San Pedro de Atacama, Chile: A Petrographic Study of Pottery from Coyo Aldea. Master's Thesis, School of Anthropology, University of Arizona, Tucson.

Ekengren, F. 2013. Contextualising grave goods: theoretical perspectives and methodological implications. In The Oxford Handbook of the Archaeology of Death and Burial, edited by S. Tarlow, and L. Nilsson Stutz, pp. 173-192. Oxford University Press, Oxford.

Fernández, J. 1978. Los chichas, los lipes y un posible enclave de la cultura de San Pedro de Atacama en la puna limítrofe argentino-boliviana. Estudios Atacameños 6:19-35.

Graffam, G. 1995. Informe preliminar. Aldea de Coyo, San Pedro de Atacama. Unpublished report held in the library of the Instituto de Investigación Arqueológica y Museo Gustavo Le Paige, San Pedro de Atacama.

Harper, S. 2010. The social agency of dead bodies. Mortality 15:308-322.

Harper, S. 2012. 'I'm glad she has her glasses on. That really makes the difference': Grave goods in English and American death rituals. Journal of Material Culture 17:43-59.

Hastorf, C.A. 2008. The Formative Period in the Titicaca Basin. In Handbook of South American Archaeology, edited by H. Silverman, and W.H. Isbell, pp. 545-561. Springer, New York.

Isbell, W.H. 2004. Mortuary preferences: A Wari culture case study from Middle Horizon Peru. Latin American Antiquity 15:3-32.

Janusek, J.W. 2004. Tiwanaku and its precursors: recent research and emerging perspectives. Journal of Archaeological Research 12:121-183.

Janusek, J.W. 2006. The changing 'nature' of Tiwanaku religion and the rise of an Andean state. World Archaeology 38:469-492.

Killion, T.W., J.A. Sabloff, G. Tourtellot, and N.P. Dunning 1989. Intensive surface collection of residential clusters at terminal classic Sayil, Yucatan, Mexico. Journal of Field Archaeology 16:273-294.

Lancaster, J. 1986. Wind action on stone artifacts: an experiment in site modification. Journal of Field Archaeology 13:359-363.

Le Paige, G. 1964. El precerámico en la cordillera atacameña y los cementerios del período agroalfarero en San Pedro de Atacama. Anales de la Universidad del Norte 3:49-93.

Le Paige, G. 1977. Recientes descubrimientos arqueológicos en la zona de San Pedro de Atacama. Estudios Atacameños 5:109-124.
Lewarch, D.E., and M.J. O'Brien 1981. The expanding role of surface assemblages in archaeological research. Advances in Archaeological Method and Theory 4:297-342.

Llagostera, A., and M.A. Costa 1999. Patrones de asentamiento en la época agroalfarera de San Pedro de Atacama (norte de Chile). Estudios Atacameños 17:175-206.

Llagostera, A., A.M. Barón, and L. Bravo 1984. Investigaciones arqueológicas en Tulor-1. Estudios Atacameños 7:133-151.

Llagostera, A., M.A. Costa, and F. Téllez 1988. Informe FONDECYT 1016/86: Interacciones transandinas en la formación y consolidación de la cultura San Pedro. Manuscript housed in the FONDECYT Archives, Anexo del Archivo Nacional con Guillermo Torres, Santiago, Chile.

López, M. 2013 Miniaturas andinas como imágenes materiales del bienestar, la fertilidad y la abundancia en Jujuy, Argentina. Estudios Avanzados 18:47-74.

Munizaga, C. 1963. Tipos Cerámicos del sitio Coyo en la Región de San Pedro de Atacama. Congreso Internacional de Arqueología de San Pedro de Atacama. Anales de la Universidad del Norte 2:99-130.

Nado, K.L., S.J. Marsteller, L.M. King, B.M. Daverman, C. Torres-Rouff, and K.J. Knudson 2012. Examining local social identities through patterns of biological and cultural variation in the Solcor ayllu, San Pedro de Atacama, Chile. Chungara Revista de Antropología Chilena 44:341-357.

Nielsen, A.E., M.M. Vázquez, J.C. Ávalos, and C.I. Angiorama 1999. Prospecciones arqueológicas en la reserva 'Eduardo Avaroa' (sud Lípez, dpto. Potosí, Bolivia). Relaciones de la Sociedad Argentina de Antropología 24:95-124.

Núñez, L. 1965 Desarrollo cultural prehispánico del norte de Chile. Estudios Arqueológicos 1:37-115.

Núñez, L. 1999. Fase Tilocalar: Nuevas evidencias formativas en la Puna de Atacama (norte de Chile). In Formativo Sudamericano. Homenaje a A.R. González y B. Meggers, edited by P. LedergerberCrespo, pp. 227-242. Departamento de Antropología, Museo de Historia Natural, Smithsonian Institution, Washington DC.

Núñez, L. 2005. La naturaleza de la expansión aldeana durante el Formativo Tardío en la cuenca de Atacama. Chungara Revista de Antropología Chilena 37:165-193.

Núñez, L. 2006. Asentamientos formativos complejos en el centro sur andino: cuando la periferia se constituye en núcleo. Simposio "Procesos y expresión de poder, identidad y orden tempranos en Sudamérica", Primera Parte. Boletín de Arqueología PUCP 10:321-356.

Núñez, L., I. Cartajena, C. Carrasco, P. De Souza, and M. Grosjean 2006. Emergencia de comunidades pastoralistas formativas en el sureste de la Puna de Atacama. Estudios Atacameños 32:93-117.

Núñez, L., and C.M. Santoro 2011. El tránsito arcaico-formativo en la circumpuna y valles occidentales del centro sur andino: hacia los cambios "neolíticos". Chungara Revista de Antropología Chilena 43:487-530.

Núñez, L., P. De Souza, I. Cartajena, and C. Carrasco 2007. Quebrada Tulán: evidencias de interacción circumpuneña durante el Formativo Temprano en el sureste de la cuenca de Atacama. In Producción y Circulación de Bienes en el Sur Andino, edited by 
A. Nielsen, C. Rivolta, V. Seldes, M. Vásquez, and P. Mercolli, pp. 287-304. Editorial Brujas, Córdoba.

Oakland Rodman, A. 1992. Textiles and ethnicity: Tiwanaku in San Pedro de Atacama, north Chile. Latin American Antiquity 3:316-340.

Orellana, M., 1963. La Cultura de San Pedro. Arqueología Chilena 3:3-43.

Orellana, M. 1964. Acerca de la Cronología del Complejo Cultural de San Pedro de Atacama. Antropología 2:96-104.

Orellana, M. 1968. Tipos alfareros en la zona del río Salado. Boletín de Prehistoria de Chile 1:3-32.

Orellana, M. 1988-89. Los tipos alfareros tempranos de Calar y su contexto aldeano. Paleoetnológica 5:73-86.

Potter, J.M., and E.M. Perry 2011. Mortuary features and identity construction in an early village community in the American Southwest. American Antiquity 76:529-546.

Roddick, A.P., and C.A. Hastorf 2010. Tradition brought to the surface: Continuity, innovation and change in the Late Formative period, Taraco Peninsula, Bolivia. Cambridge Archaeological Journal 20:157-178.

Schiffer, M.B. 1987. Formation Processes of the Archaeological Record. University of New Mexico Press, Albuquerque.

Serracino, G. 1976. Tulor 4: 4 pozos de sondeo. Estudios Atacameños 4:24-31.

Shimada, I., K. Shinoda, J. Farnum, R. Corruccini, and H. Watanabe 2004. An integrated analysis of prehispanic mortuary practices: a middle Sican case study. Current Anthropology 45:369-402.

Sinclaire, C. 2004. Prehistoria del período Formativo en la cuenca alta del río Salado (Región del Loa superior). Chungara Revista de Antropología Chilena 36:619-639.

Sinclaire, C., M. Uribe, P. Ayala, and J. González 1998. La alfarería del período Formativo en la región del Loa Superior: sistematización y tipología. Actas del XIV Congreso Nacional de Arqueología Chilena. Contribuciones Arqueológicas 5:285-314.

Stovel, E.M. 1997. Habitational Analysis and Cultural Contact at Coyo Aldea, Northern Chile: The Surface Deposits. Master's Thesis, Department of Anthropology, State University of New York at Binghamton, New York.

Stovel, E.M. 2005. The archaeology of identity construction: ceramic evidence from northern Chile. In Global Archaeological Theory, edited by P.P. Funari, A. Zarankin, and E. Stovel, pp. 145-166. Springer/Kluwer, New York.

Stovel, E.M. 2008. Interactions and social fields in San Pedro de Atacama Northern Chile. In Handbook of South American Archaeology, edited by H. Silverman, and W. Isbell, pp. 9791004. Springer, New York.

Stovel, E.M. 2013. Prehistoric Atacameño ceramic styles and chronology reassessed. Chungara Revista de Antropología Chilena 45:371-385.

Stovel, E.M., B. Cremonte, and E. Echenique 2013. Petrography and PXRF at San Pedro de Atacama, northern Chile: exploring ancient ceramic production. In Integrative Approaches in Ceramic Petrography, edited by M. Ownby, M. Masucci, and I. Druc. University of Utah Press, Salt Lake City, in press.
Tarragó, M. 1968. Secuencias culturales de la etapa agroalfarera de San Pedro de Atacama (Chile). Actas y Memorias del $37^{\circ}$ Congreso Internacional de Americanistas, vol. 2, pp. 119-144. Buenos Aires.

Tarragó, M. 1976. Alfarería típica de San Pedro de Atacama (norte de Chile). Estudios Atacameños 4:37-64.

Tarragó, M. 1984. La historia de los pueblos circumpuneños en relación con el Altiplano y los Andes Meridionales. Estudios Atacameños 7:116-132.

Tarragó, M. 1989. Contribución al Conocimiento Arqueológico de las Poblaciones de los Oasis de San Pedro de Atacama en Relación con los Otros Pueblos Puneños, en Especial el Sector Septentrional del Valle de Calchaquí. Doctoral Dissertation, Universidad Nacional del Rosario, Rosario.

Tarragó, M. 2006. Espacios surandinos y la circulación de bienes en época de Tiwanaku. In Esferas de Interacción Prehistóricas y Fronteras Nacionales Modernas: Los Andes Sur Centrales, edited by H. Lechtman, pp. 331-376. Instituto de Estudios Peruanos / Institute of Andean Research, Lima-New York.

Thomas, C., and M.A. Benavente 1974-1975. Proposición de un modelo de análisis de fragmentación cerámica poco diagnóstica. Boletín de Prehistoria de Chile 6-7:37-58.

Thomas, C., C. Massone, and M.A. Benavente 1984. Sistematización de la alfarería del área de San Pedro de Atacama. Revista Chilena de Antropología 4:49-119.

Torres-Rouff, C., and M. Hubbe 2013. The sequence of human occupation in the Atacama Oases, Chile: a radiocarbon chronology based on human skeletal remains. Latin American Antiquity 24:330-344.

Torres-Rouff, C., K. Knudson, and M. Hubbe 2013. Issues of affinity: exploring population structure in the middle and regional developments periods of San Pedro de Atacama, Chile. American Journal of Physical Anthropology 152:370-382.

Uribe, M. 2002. Sobre alfarería, cementerios, fases y procesos durante la prehistoria tardía del desierto de Atacama (800-1600 DC). Estudios Atacameños 22:7-31.

Uribe, M. 2004. Alfarería, Arqueología y Metodología. Aporte y Proyecciones de los Estudios Cerámicos del Norte Grande de Chile. Master's thesis, Universidad de Chile, Santiago.

Uribe, M. 2006. Sobre cerámica, su origen y complejidad social en los Andes del desierto de Atacama, norte de Chile. In Esferas de Interacción Prehistóricas y Fronteras Nacionales Modernas: los Andes Sur Centrales, edited by H. Lechtman, pp. 449-494. Instituto de Estudios Peruanos / Institute of Andean Research, Lima-New York.

Uribe, M., L. Adán, and C. Agüero 2004. Arqueología de los períodos Intermedio Tardío y Tardío de San Pedro de Atacama y su relación con la cuenca del río Loa. Chungara Revista de Antropología Chilena 36:943-956.

Uribe, M., and P. Ayala 2004. La alfarería de Quillagua en el contexto Formativo del Norte Grande de Chile (1000 a.C.-500 d.C). Chungara Revista de Antropología Chilena, Volumen Especial Tomo II:585-597.

Uribe, M., and E. Vidal 2012. Sobre la secuencia cerámica del período Formativo de Tarapacá (900 a.c.-900 d.C.): 
estudios en Pircas, Caserones, Guatacondo y Ramaditas, norte de Chile. Chungara Revista de Antropología Chilena 44:209-245.

Varela, V., M. Uribe, and L. Adán 1993. La cerámica arqueológica del sitio 'pukara' de Turi: 02-TU-001. Actas del XII Congreso
Nacional de Arqueología Chilena, pp. 107-122. Museo Regional de la Araucanía, Temuco.

Vaughn, K. J. 2006. Craft production, exchange, and political power in the pre-Incaic Andes. Journal of Archaeological Research 14:313-344.

\section{Notes}

1 NP, signifying Negro Pulido, will be discarded from the nomenclature from now on as household remains include colors other than black.

2 Form VII was included with Form XIII in 1976 but separated out as a discrete type in 1989 (Tarragó 1989:45-46). It is characterized by a lack of differentiation of the lip from the rim, and was not clearly distinguishable from Form XIII in the Coyo Aldea sample. 